Structures and Materials Panel of the Advisory Group for Aeronautical Research and Development of the North Atlantic Treaty Organization and works as a co-ordinator for the Commonwealth Advisory Aeronautical Research Council.

\section{Royal Geographical Society: Medals and Awards, 1959}

H.M. THE QUEen has approved the award of the Royal Medals of the Royal Geographical Society, as follows: Patron's Medal: Commander W. R. Anderson, U.S.N., for the first trans-polar submarine voyage, in command of U.S.S. Nautilus; Founder's Medal : Sir Raymond Priestley, British observer, U.S. Antarctic Expedition, 1958-59, for services to Antarctic exploration.

The Council of the Royal Geographical Society has made the following awards: Victoria Medal: Mr. Gerald Seligman, president of British Glaciological Society, for contributions to glaciological research ; Murchison Grant: Prof. S. P. Chatterjee, professor of geography, Calcutta, for important work organizing and directing the "National Atlas of India" ; Back Grant : Mr. David Stratton, deputyleader, Commonwealth Trans-Antarctic Expedition; Cuthbert Peek Grant: Mr. W. George Lowe, for contributions to Himalayan and Antarctic exploration; Gill Memorial : Mr. G. S. Holland, chief draughtsman, Royal Geographical Society, for contributions to cartography, especially of southern Arabia; Mrs. Patrick Ness Award (jointly) : Mr. J. H. Miller, deputy-leader, New Zealand party, Commonwealth Trans-Antarctic Expedition, for contributions to Antarctic exploration, and Dr. George W. Marsh, Commonwealth Trans-Antarctic Expedition and Falkland Islands Dependencies Survey, for contributions to Antarctic exploration.

\section{British National Committee on Antarctic Research}

THE British National Committee on Antaretic Research has been set up to co-ordinate British Antarctic activities in relation to the large scientific programme at present being considered by the Special Committee on Antarctic Research of the International Council of Scientific Unions. This programme includes meteorology, ionospheric studies, auroral physics, geomagnetism, cosmic rays, geology, glaciology, geomorphology, cartography, seismology, gravity, vulcanology, oceanography, sea ice, biology including marine aspects and physiology. The members of the new National Committee are : Chairman, Sir Raymond Priestley ; Royal Society : Prof. W. V.D. Hodge, Sir Lindor Brown, Dr. H. G. 'Thornton, Mr. A. H. Sheffield, Prof. F. W. Shotton, Prof. J, E. Smith, Dr. R. L. Smith-Rose, Dr. R. Stoneley and Sir James Wordie; Sir Vivian Fuchs, scientific director, Falkland Islands Dependencies Survey; Brig. M. Hotine, director, Overseas Surveys; Rear-Admiral K. St. B. Collins, hydrographer of the Navy; Dr. G. E. R. Deacon, director, National Institute of Oceanography ; Sir Graham Sutton, director-general, Meteorological Office; Dr. G. de Q. Robin, United Kingdom delegate to the Special Committee of Antarctic Research; Sir Miles Clifford, Royal Geographical Society; Dr. E. Hindle, Royal Geographical Society; Mr. G. Seligman, British Glaciological Society; Dr. S. Evans, Scott Polar Research Institute; Mr. J. Paton, Royal Society of Edinburgh; Dr. L. G. C. E. Pugh, Medical Research Council; and Mr. H. H. Lamb, Royal Meteorological Society.

\section{Safety and the Nuclear Power Industry}

Tre hazards which nuclear power stations present were raised by Mr. G. Roberts in an adjournment debate in the House of Commons on January 21. In reply, Sir Ian Horobin, Parliamentary Secretary to the Ministry of Power, said that on the best evidence available there is no danger of radioactive strontium from nuclear power stations in areas of high rainfall like north-west Wales adversely affecting the water supply. Further, although the amount of radioactive strontium descending from the stratosphere is increasing at the present rate, it will be several generations before the equilibrium-level built up in the bones of the population reaches the amber band. The increase in leukrmia began a generation before the first nuclear tests, and there are at present no statistically significant differences, either by area or in time, in the incidence of this disease ; specifically there is no statistical difference between north Wales and other parts of the United Kingdom. In the normal operation of a nuclear power station certain radioactive substances might go up the stack but their life is so short that they can be ignored, as can seepage. As regards the release of coolants, monitoring is done with such extreme care that hazard is unlikely. The Wigner type of release which led to the Windscale accident will not be necessary in the new stations where the coolant, carbon dioxide, will operate in a closed circuit. Sir Ian thought that only in very exceptional circumstances could an accident lead to serious contamination and assured the House that Britain is in the forefront not only of constructional ingenuity but also in safety devices in this field.

\section{Glass in Nuclear Research}

IMPORTANT developments in nuclear research in recent years have meant an increased demand for viewing windows to permit clear observation of operations or objects within the bounds of the 'hot' cell walls, and also to facilitate the remote handling of radioactive materials, while providing protection for the operatives. Just as ingenious mechanisms have been evolved for remote handling, so have special types of glass been produced for shielding windows. The Chance-Pilkington Optical Works, at St. Asaph, North Wales, has now developed radiationabsorbing glasses of larger dimensions than have been available hitherto in Europe. Particularly at very short wave-lengths, the attenuation offered by protective walling is proportional to the density of the material employed. The Chance-Pilkington shielding glasses range in density from $2.5 \mathrm{gm}$. per e.c. to $6 \cdot 1 \mathrm{gm}$. per c.e., and allow the design of windows to be, in many cases, of equal thickness to the surrounding wall, thereby reducing the complexity of additive shielding and obtaining the maximum optical advantage from the window.

Upon receipt of large doses of short wave-length radiation, glasses of normal composition tend to discolour to a deep yellow or brown. To overcome this, Chance-Pilkington manufacture a series of glasses which are stabilized. These glasses have amended compositions having the effect of slightly decreasing the transmission of the glass in the unirradiated state, but reducing the tendency for further discoloration under conditions of radiation. Shielding glasses of density $2.5 \mathrm{gm}$. per c.e. and $4.3 \mathrm{gm}$. per c.c. are manufactured in polished plate form and also in block form up to $4 \mathrm{ft}$. 6 in. by $3 \mathrm{ft}$. in area and $10 \mathrm{in}$. in thickness, with the limitation 